\title{
True grit: ingestion of small stone particles by hummingbirds in West Mexico
}

\author{
Omar Maya-García ${ }^{1,2}$, Mauricio Ortega-Flores ${ }^{2}$ and Jorge E. Schondube $2^{2^{*}}$
}

\begin{abstract}
Background: Grit is used by birds mainly for grinding hard food items but can also serve a nutritional role as a source of minerals. Ingestion of grit by birds has been documented primarily in species that feed on seeds and invertebrates. Although feeding mainly on nectar and small arthropods, hummingbirds also ingest grit, but why they do so is unclear. We quantified the number of grit particles in the stomachs of six species of hummingbirds during an annual cycle in a seasonal ecosystem of West Mexico.
\end{abstract}

Methods: We compared the number of grit particles in the stomachs of different hummingbird species (Mexican Violetear Colibri thalassinus, Amethyst-throated Mountaingem Lampornis amethystinus, White-eared Hummingbird Basilinna leucotis, Rivoli's Hummingbird Eugenes fulgens, Broad-tailed Hummingbird Selasphorus platycercus, and Rufous Hummingbird S. rufus), and between sex and age categories during the different seasons of a year. To determine if grit was used to grind ingested arthropods, we examined the relationships between the number of grit particles, the biomass of arthropods ingested, and their chitin content.

Results: Although species did not differ in the number of grit particles in their stomachs, we found that grit was mostly ingested by female individuals, with only one male of one species (Mexican Violetear) presenting grit in its stomach. We also found that female hummingbirds had grit in their stomachs during the rainy and the cold-dry season (June-February) but not during the warm-dry season (March-May). Our analyses revealed no relationship between the number of grit particles and the amount of ingested arthropods and arthropod chitin content. However, high grit consumption was related to wasp ingestion on Mexican Violetears.

Conclusions: Our results indicate that grit is used mainly by female hummingbirds. The seasonal variation in the ingestion of grit by female individuals suggests that it can be used to meet mineral requirements related to breeding; however, this topic needs further exploration. Additionally, the use of grit was proportionally higher in juvenile individuals, suggesting it is used for grinding arthropods during a period of fast development.

Keywords: Arthropod chitin content, Arthropod digestion, Breeding season, Mineral nutritional requirements

*Correspondence: chon@cieco.unam.mx

${ }^{2}$ Laboratorio de Ecología Funcional, Instituto de Investigaciones en Ecosistemas y Sustentabilidad, Universidad Nacional Autónoma de México, Antigua Carretera a Pátzcuaro No. 8701, Col. Ex Hacienda de San José de la Huerta, C.P. 58190 Morelia, Michoacán, Mexico

Full list of author information is available at the end of the article

\section{Background}

Grit, defined as small stones or tiny rock fragments, is ingested by many bird species to facilitate the mechanical grinding of ingested hard food items (Ziswiler and Farner 1972; Brown 1976; Barrentine 1980; Bishton 1986; Gionfriddo and Best 1999). However, grit can also serve as a source of minerals such as calcium (Sadler 1961; Harper 1964; Korschgen 1964; Campbell and Leatherland 1983; Adam and des Lauriers 1998). Ingestion of grit by birds has also been found to be influenced by the hardness of original author(s) and the source, provide a link to the Creative Commons licence, and indicate if changes were made. The images or other third party material in this article are included in the article's Creative Commons licence, unless indicated otherwise in a credit line to the material. If material is not included in the article's Creative Commons licence and your intended use is not permitted by statutory regulation or exceeds the permitted use, you will need to obtain permission directly from the copyright holder. To view a copy of this licence, visit http://creativecommons.org/licenses/by/4.0/. The Creative Commons Public Domain Dedication waiver (http://creativeco mmons.org/publicdomain/zero/1.0/) applies to the data made available in this article, unless otherwise stated in a credit line to the data. 
ingested food (Bird and Smith 1964; Mott et al. 1972; Alonso 1985; Gionfriddo and Best 1996) and by changes in mineral requirements, particularly during egg production and periods of accelerated growth (Harper 1963; Kopischke and Nelson 1966; Taylor 1970; Johnson and Barclay 1996; Reynolds 1997).

Although many different species of birds ingest grit, few research papers have documented the use of grit by hummingbirds. In these reports, different species of hummingbirds ingested materials such as wood ashes, lime dust, sand particles, and small rocks of different geological origins (Haverschmidt 1952; Verbeek 1971; des Lauriers 1994; Adam and des Lauriers 1998; Graves 2007; Estades et al. 2008; Hickman et al. 2012; See Additional file 1: Table S1 for details). Interestingly, most reports of grit ingestion by hummingbirds have been of females during the breeding season (Haverschmidt 1952; Verbeek 1971; des Lauriers 1994; Adam and des Lauriers 1998; Graves 2007; Hickman et al. 2012; Additional file 1: Table S1). As a result, some authors have suggested that female hummingbirds ingest mineral-rich grit to obtain calcium for eggshell production (Verbeek 1971; des Lauriers 1994; Adam and des Lauriers 1998; Graves 2007; Estades et al. 2008; Hickman et al. 2012). However, female hummingbirds also consume more, and higher quality arthropods (e.g. spiders) during the breeding season to provide protein for egg production and to provision nestlings (Hainsworth 1977; Montgomerie and Redsell 1980; Chavez-Ramirez and Down 1992; Stiles 1995; Murphy 1996; Rico-Guevara 2008), so grit could also be used to aid in the mechanical digestion of these arthropods (Ziswiler and Farner 1972; Brown 1976; Barrentine 1980; Bishton 1986; Gionfriddo and Best 1999).

Our objective was to quantify the number of grit particles in the stomachs of several species of hummingbirds and to explore the possible function of grit ingestion by hummingbirds. Specific objectives were to determine: (1) the extent to which hummingbirds ingest grit and how many grit particles are present in their stomachs, (2) if grit ingestion varies seasonally, (3) if there are differences in the use of grit by sex (females vs. males) and age classes (juveniles vs. adults), and (4) if there is a relationship between the number of grit particles in hummingbird stomachs, the quantity of arthropods ingested, and the chitin content of ingested arthropods.

Because the amount of arthropods ingested by hummingbirds changes seasonally with the availability of food resources at our study site, we expected hummingbirds to ingest more grit when they ingested more arthropods. In addition, because the number of grit particles increases in response to food hardness in other species of birds (Bird and Smith 1964; Mott et al. 1972; Alonso 1985; Gionfriddo and Best 1996), we expected that hummingbirds that consumed arthropods with greater chitin content would have more grit particles in their stomachs than those that feed on softer arthropods. Finally, because females ingest more arthropods than males during the breeding season to meet the higher nutritional and energy requirements of producing eggs and parental care (Hainsworth 1977; Montgomerie and Redsell 1980; Chavez-Ramirez and Down 1992; Stiles 1995; Murphy 1996; Rico-Guevara 2008), we expected those female hummingbirds would have more grit particles in their stomachs than adult males.

\section{Methods \\ Study site}

Our study was conducted at the Nevado de Colima National Park (NCNP) in Jalisco, Mexico. Nevado de Colima is an inactive high-altitude volcano ( $4260 \mathrm{~m}$ a.s.l.) located at the western end of the Trans-Mexican Volcanic Belt $\left(19^{\circ} 33^{\prime} 45^{\prime \prime}-19^{\circ} 30^{\prime} 40^{\prime \prime} \mathrm{N}, 103^{\circ} 36^{\prime} 30^{\prime \prime}-103^{\circ}\right.$ $37^{\prime} 30^{\prime \prime} \mathrm{W}$; INEGI 2011). The climate in the region is highly seasonal (CONANP 2006, 2017). Our study site was located at $3194 \mathrm{~m}$ a.s.l. and consisted of subalpine scrublands (dominated by plants of the genus Salvia, Ribes, and Festuca), some scattered alders (Alnus) on exposed ridges, and pine and fir forests (Pinus and Abies) located in ravines (Schondube 2012). The most important flowering plants that hummingbirds feed on include Salvia elegans, S. gesneriflora (Lamiaceae), Ribes ciliatum (Saxifragaceae), Senecio angulifolius (Asteraceae), and Penstemon roseus (Plantaginaceae) (Schondube 2012).

\section{Fieldwork}

We sampled hummingbirds three times over a one-year period. Our sampling corresponded with the three climatic seasons in the region, including (1) a rainy season from June to October, (2) a cold-dry season from November to February, and (3) a warm-dry season from March to May (CONANP 2006, 2017). We selected this sampling scheme because weather conditions and the availability of floral nectar and arthropods varied widely among these three seasons (CONANP 2006, 2017). We sampled during May and September 2016, and February 2017. During each sampling period, we captured hummingbirds using 10 mist-nets (12-m long, 24-mm mesh) for three consecutive days. Mist-nets were opened at sunrise and closed after $6 \mathrm{~h}$. Net rounds were conducted every $5 \mathrm{~min}$. We located the mist-nets within a 2 ha area, and their location remained constant during the study. We identified all captured birds and recorded their age and sex using plumage characteristics and bill striations (Williamson 2001; Howell 2002; Russell et al. 2019). Additionally, for the Mexican Violetear, the only species that did not present a clear sexual dimorphism in plumage at our 
study site we used wing chord length and bill tip serrations to determine their sex (Rico-Guevara et al. 2019). Data on wing chord differences among sexes for this species was obtained from a 30-year hummingbird banding program located in the same region. We define females as those individuals with a wing chord $<60 \mathrm{~mm}$, and males as those individuals with a wing chord $>63 \mathrm{~mm}$ (Contreras-Martínez personal communication).

\section{Stomach content analysis}

We obtained the stomachs of hummingbirds collected as part of an independent stable isotope project conducted at our study site ( $n=6$ in May 2016, $n=8$ in September 2016, and $n=37$ in February 2017). That study collected blood, liver, pectoral muscle, and bones to extract collagen, and allowed us to use the stomachs. The remaining feathers, skulls, and tongues were deposited at the collection of the Functional Ecology Laboratory of IIES, UNAM. Samples were collected with permission from the Secretaría de Medio Ambiente y Recursos Naturales, Mexico (SGPA/DGGFS/712/2767/14). All collected birds were humanely euthanized by carefully placing their heads inside a small vial that contained a cotton ball soaked in isoflurane, following the guidelines to the use of wild birds in research (Fair et al. 2010), and their stomachs were placed in plastic vials with saline solution $(0.8 \%$ $\mathrm{NaCl}$ ) and frozen in liquid nitrogen until processed in the laboratory. The time between hummingbird capture in the nets and stomach freezing was less than $20 \mathrm{~min}$. Because soft arthropods require 3-4 $\mathrm{h}$ to be digested completely by hummingbirds (Remsen et al. 1986), this time frame allowed us to quantify stomach arthropod content at the moment of capture. The species sampled were: Mexican Violetear (Colibri thalassinus), Amethyst-throated Mountaingem (Lampornis amethystinus), White-eared Hummingbird (Basilinna leucotis), Rivoli's Hummingbird (Eugenes fulgens), Broad-tailed Hummingbird (Selasphorus platycercus), and Rufous Hummingbird (S. rufus). The number of individuals collected at each season differed due to variation in capture rates among seasons, and due to restrictions on collecting permits (maximum of 10 individuals per species per season).

We analyzed hummingbird stomachs in the lab to determine the number of grit particles they contained. Stomachs were thawed and dissected, and their contents removed. We quantified grit particles by carefully separating them from the arthropod remains in hummingbird stomachs using a stereoscopic microscope (AmScope, 7-45 $\times$ binocular stereo zoom microscope). We described the color and shape, and weighed and measured grit particles. To determine their size, we determined the grit area by taking a picture of each grit particle on top of a millimetric grid. Images were analyzed using ImageJ (National Institute of Health, $\mathrm{NIH}$ Version v1.32j). Because the role of grit as either a grinding agent or nutritional supplement depends upon its hardness and solubility in the digestive tract (Meinertzhagen 1954; Myrberget et al. 1975; Gionfriddo and Best 1999), we determined grit hardness. We did this by pressing each grit particle twice with fine-point reverse action tweezers. This kind of tweezer allowed us to generate a standard pressure on the grit particle and separate them into two hardness categories: hard (did not break) and soft (did break into smaller pieces).

\section{Physical and chemical characterization of grit particles}

We used scanning electron microscopy (SEM) and energy dispersive X-ray (EDX) spectroscopy (Tabletop Microscope Hitachi, Model TM3030Plus) to perform the physical and chemical characterization of the grit particles. Because soft grit broke into tiny particles, we were only able to analyze the hard grit particles. Of these, due to the limitations imposed by the method, we were able to analyze only the largest hard grit particles (diameter of $0.5-1 \mathrm{~mm}, n=5$ ). Analyses were carried out in the Microanalysis Laboratory of the Geophysics Institute, UNAM.

\section{Ingested arthropod biomass and chitin content}

We separated all arthropod remains into those that were identifiable (arthropods partially fragmented) and those that were not (very fragmented arthropods) using a stereoscopic microscope. We identified recognizable arthropods to the taxonomic level of order following Triplehorn and Johnson (2005). To determine the biomass of ingested arthropods (g dry mass), we dried both identifiable and unidentifiable arthropod samples at room temperature for $3 \mathrm{~h}$ and then weighed them using an analytical balance (Ohaus Adventurer, capacity/readability of $110 \mathrm{~g} \times 0.001 \mathrm{~g}$ ). Chitin content (percent dry mass) of the different identified arthropod orders was obtained from Rothman et al. (2014). We estimated the mean chitin content of arthropods by averaging the percent chitin content of the different arthropod orders present.

\section{Data analysis}

We used different analyses to test our main hypotheses on the use of grit particles by hummingbirds. First, we compared the number of grit particles present in hummingbird stomachs among species using a KruskalWallis test (Zar 1999). We used a non-parametric test because our data did not present a normal distribution. In view of the fact that we did not find grit particles in the stomachs of hummingbirds during the warm-dry season, and due to the small sample size of the rainy season, this analysis was limited to our data for the cold-dry season. 
Second, we used a generalized linear model (GLM) to assess whether the number of grit particles (response variable) varied among seasons, and between age and sex classes. In this model, we include season (warm-dry, rainy, and cold-dry seasons), age (adult and juvenile individuals), and sex (female and male individuals) as categorical explanatory variables. We select for this analysis the data of all 25 male and 21 female individuals sampled, excluding data from the 5 individuals whose sexes were unknown. Due to our small sample size, we created a 0-1 binary response variable in which 0 represented the absence of grit and 1 represented the presence of grit, and fitted our model with a Binomial distribution and a logit link function. Additionally, we used the adjusted maximum likelihood estimator for reducing biases of the Binomial logistic regression parameters (following Firth 1993).

Third, because the two response variables of arthropod ingestion (i.e. the biomass of arthropods ingested and their chitin content) presented different distributions, we ran two GLMs with the number of grit particles as the explanatory variable, whereas the response variables differed. For GLM 1, we used the biomass of ingested arthropods (g dry mass) as the response variable and a normal distribution with an identity link function. For GLM 2, we used the chitin content of arthropods ingested by hummingbirds (percent dry mass) as the response variable, and a Poisson distribution with a Log link function. In both models, we only included the data from those individuals whose stomachs presented grit particles ( $n=12$ for GLM 1, and $n=8$ for GLM 2; Additional file 1: Table S2).

Finally, we performed some tests to search for differences in the arthropod content and grit particles characteristics between individuals of both sexes. Since we only had a male individual, we use the data of the females to construct a confidence interval to compare it against the male values using a one-sample $t$-test for those variables with normal distributions (number of grit particles and the biomass of ingested arthropods), and a Wilcoxon test for non-normal distributed data (size of grit particles; Sokal and Rohlf 1995). We conducted all analyses using JMP version 9.0 (SAS Institute Inc.). Values are provided as means $\pm \mathrm{SD}$.

\section{Results}

Characteristics of grit particles ingested by hummingbirds Grit particles were of two types: crystal-like or opaque and non-crystalline. The average mass of grit particles was $0.057 \pm 0.042 \mathrm{mg}(n=50)$. The average size of the larger flat side of ingested grit particles was $0.52 \pm 0.38$ $\mathrm{mm}^{2}(n=50)$. We found that $70 \%$ of the grit particles did not break when pressed with the tip of the tweezers (classified as hard, all crystal-like), whereas the other 30\% broke after the first or second pressing (classified as soft, mostly opaque, and non-crystalline particles, and a few crystal-like particles).

Examination of hard grit particles using both a stereoscopic and a scanning electron microscope revealed that they were black, angular to rounded, and very porous (i.e. with vesicles; Fig. 1). Additionally, spectroscopy analysis (EDX) revealed that grit particles had high concentrations of oxygen and silicon $(40.5 \pm 5.8 \%$ and $20.5 \pm 2.5 \%$ of total mass, respectively, mean $\pm \mathrm{SD}, n=5)$, and low levels of minerals such as calcium and sodium $(<10 \%$ of total mass; Table 1). Based on their physical characteristics and chemical composition, hard grit particles analyzed were classified as volcanic glasses (Sosa-Ceballos personal communication).

\section{Use of grit particles by hummingbirds}

We found that 12 of the 51 hummingbird stomachs analyzed $(23.5 \%)$ presented grit particles. The majority of collected hummingbird species, including Mexican Violetears, Amethyst-throated Mountaingems, White-eared Hummingbirds, Rivoli's Hummingbirds, and Broadtailed Hummingbirds, had grit particles in their stomachs (Table 2). Only one species, the Rufous Hummingbird, did not present grit particles. From the birds that presented grit particles, 8 stomachs belonged to female hummingbirds and only one to a male individual. We were unable to determine the sex of the other 3 individuals that presented grit in their stomachs. The only male that presented grit in its stomach had a total of 61 particles, a number that was larger than the average number of grit particles found in the stomachs of female hummingbirds $(2.0 \pm 0.75, n=8)$. When we compared the mean value of the number of grit particles for females and the value of the only male, we found a significant difference $\left(t_{8}=-220.8, P<0.0001\right)$. Grit particles found inside the male's stomach had similar color and shape to those present in the females. While grit particles in the male hummingbird tended to present larger areas than those found in the stomachs of females, this difference was not significant $\left(\chi_{1,71}^{2}=3.7, P=0.053\right)$.

During the warm-dry season, we found no grit particles in hummingbird stomachs (Table 2; Fig. 2). Based on our binomial model, we found that the variation in the use of grit particles in hummingbird stomachs among the three seasons was not significant (Table 3). The percentage of individuals with grit in their stomachs varied among seasons: $50 \%$ (four of eight sampled individuals) during the rainy season, $21.6 \%$ (eight of 37 sampled) during the cold-dry season, and $0 \%(0$ of 6 sampled) during the warm-dry season (Table 2; Fig. 2). The average number of grit particles found in 


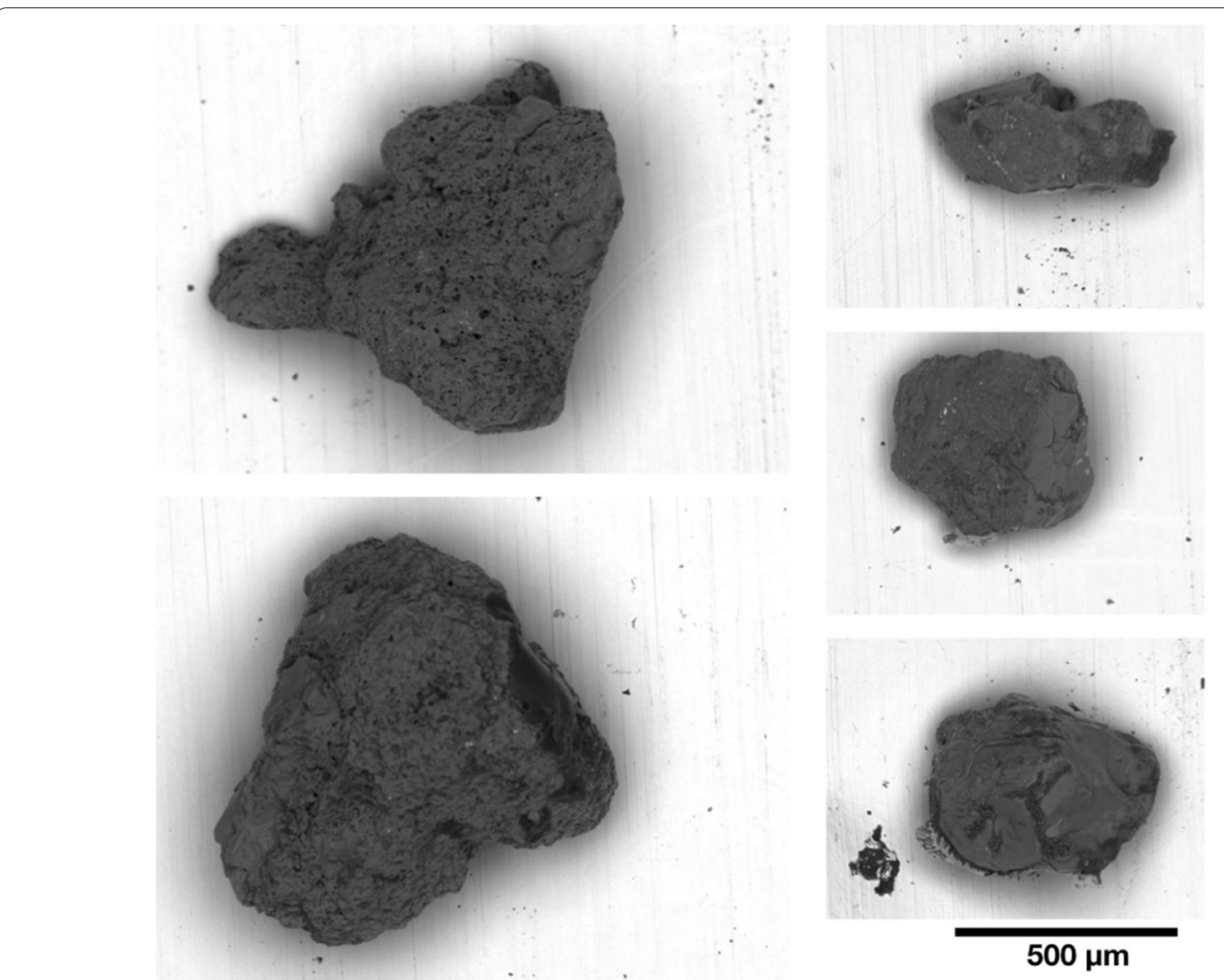

Fig. 1 Morphology of hard grit particles present in the stomachs of Mexican Violetears. All grit particles are presented at the same scale. Pictures were taken at $5 \mathrm{kV}$ using a Hitachi TM3030

Table 1 Chemical composition of hard grit particles found in the stomachs of Mexican Violetears (average grit particle mass $=0.3 \pm 0.1 \mathrm{mg}, n=5$ )

\begin{tabular}{|c|c|c|c|c|c|c|}
\hline \multirow[t]{2}{*}{ Element } & \multicolumn{5}{|c|}{ Percent of total mass (\%) } & \multirow[t]{2}{*}{ Mean \pm SD } \\
\hline & Grit 1 & Grit 2 & Grit 3 & Grit 4 & Grit 5 & \\
\hline O & 46 & 32.8 & 46.4 & 38.3 & 38.8 & $40.5 \pm 5.8$ \\
\hline $\mathrm{Si}$ & 17.8 & 20.2 & 23.9 & 18.6 & 21.9 & $20.5 \pm 2.5$ \\
\hline C & 15.3 & 0 & 13 & 0 & 11.3 & $7.9 \pm 7.4$ \\
\hline Al & 8.1 & 5.1 & 6.5 & 1.1 & 6.8 & $5.5 \pm 2.7$ \\
\hline $\mathrm{Cu}$ & 0 & 10.7 & 6.9 & 0 & 5.01 & $4.5 \pm 4.6$ \\
\hline $\mathrm{Mg}$ & 0 & 3.4 & 0 & 13.1 & 0 & $3.3 \pm 5.7$ \\
\hline $\mathrm{Ca}$ & 3 & 7.7 & 0 & 0.7 & 2.7 & $2.8 \pm 3$ \\
\hline $\mathrm{Na}$ & 2.5 & 0 & 4.1 & 2 & 0 & $1.7 \pm 1.7$ \\
\hline $\mathrm{Fe}$ & 4 & 0 & 0 & 0 & 0 & $0.8 \pm 1.8$ \\
\hline K & 0 & 0 & 0 & 0 & 1 & $0.2 \pm 0.5$ \\
\hline Total & 96.8 & 79.9 & 100 & 73.8 & 87.6 & $87.8 \pm 11.3$ \\
\hline
\end{tabular}

Elements are presented in order of importance. Elementary analyses were performed using energy dispersive X-ray spectroscopy (EDX) 
Table 2 Number of grit particles per stomach (mean \pm SD for $n>1$ ) of the different members of a hummingbird ensemble in a seasonal ecosystem of West Mexico

\begin{tabular}{|c|c|c|c|c|c|c|}
\hline Season & Individual & Species & Age & Sex & $\begin{array}{l}\text { Grit particles per } \\
\text { stomach }\end{array}$ & $\begin{array}{l}\text { Mean number of grit particles } \\
\text { per species per season } \pm \text { SD }\end{array}$ \\
\hline \multirow[t]{6}{*}{ Warm-dry } & 1 & Amethyst-throated Mountaingem & Adult & Female & 0 & \\
\hline & 2 & White-eared Hummingbird & Adult & Male & 0 & \\
\hline & 3 & White-eared Hummingbird & Adult & Male & 0 & \\
\hline & 4 & White-eared Hummingbird & Adult & Male & 0 & \\
\hline & 5 & White-eared Hummingbird & Adult & Male & 0 & \\
\hline & 6 & Rivoli's Hummingbird & Adult & Female & 0 & \\
\hline \multirow[t]{8}{*}{ Rainy } & 7 & Mexican Violetear & Adult & Female & 2 & $2.5 \pm 3.1(n=4)$ \\
\hline & 8 & Mexican Violetear & Adult & Unknown & 7 & \\
\hline & 9 & Mexican Violetear & Adult & Unknown & 0 & \\
\hline & 10 & Mexican Violetear & Juvenile & Unknown & 1 & \\
\hline & 11 & Amethyst-throated Mountaingem & Adult & Female & 1 & \\
\hline & 12 & White-eared Hummingbird & Juvenile & Female & 0 & \\
\hline & 13 & Rivoli's Hummingbird & Adult & Male & 0 & \\
\hline & 14 & Rivoli's Hummingbird & Adult & Female & 0 & \\
\hline \multirow[t]{37}{*}{ Cold-dry } & 15 & Mexican Violetear & Adult & Male & 0 & $11.3 \pm 24.4(n=6)$ \\
\hline & 16 & Mexican Violetear & Adult & Male & 61 & \\
\hline & 17 & Mexican Violetear & Adult & Female & 2 & \\
\hline & 18 & Mexican Violetear & Adult & Unknown & 0 & \\
\hline & 19 & Mexican Violetear & Juvenile & Male & 0 & \\
\hline & 20 & Mexican Violetear & Juvenile & Unknown & 5 & \\
\hline & 21 & Amethyst-throated Mountaingem & Adult & Male & 0 & \\
\hline & 22 & White-eared Hummingbird & Adult & Male & 0 & $0.2 \pm 0.6(n=9)$ \\
\hline & 23 & White-eared Hummingbird & Adult & Male & 0 & \\
\hline & 24 & White-eared Hummingbird & Adult & Male & 0 & \\
\hline & 25 & White-eared Hummingbird & Adult & Male & 0 & \\
\hline & 26 & White-eared Hummingbird & Adult & Male & 0 & \\
\hline & 27 & White-eared Hummingbird & Adult & Male & 0 & \\
\hline & 28 & White-eared Hummingbird & Adult & Female & 2 & \\
\hline & 29 & White-eared Hummingbird & Juvenile & Male & 0 & \\
\hline & 30 & White-eared Hummingbird & Juvenile & Male & 0 & \\
\hline & 31 & Rivoli's Hummingbird & Adult & Male & 0 & $0.1 \pm 0.3(n=8)$ \\
\hline & 32 & Rivoli's Hummingbird & Adult & Male & 0 & \\
\hline & 33 & Rivoli's Hummingbird & Adult & Female & 0 & \\
\hline & 34 & Rivoli's Hummingbird & Adult & Female & 0 & \\
\hline & 35 & Rivoli's Hummingbird & Adult & Female & 0 & \\
\hline & 36 & Rivoli's Hummingbird & Adult & Female & 1 & \\
\hline & 37 & Rivoli's Hummingbird & Adult & Female & 0 & \\
\hline & 38 & Rivoli's Hummingbird & Juvenile & Male & 0 & \\
\hline & 39 & Broad-tailed Hummingbird & Adult & Male & 0 & $0.8 \pm 1.3(n=9)$ \\
\hline & 40 & Broad-tailed Hummingbird & Adult & Male & 0 & \\
\hline & 41 & Broad-tailed Hummingbird & Adult & Female & 0 & \\
\hline & 42 & Broad-tailed Hummingbird & Adult & Female & 0 & \\
\hline & 43 & Broad-tailed Hummingbird & Adult & Female & 3 & \\
\hline & 44 & Broad-tailed Hummingbird & Adult & Female & 0 & \\
\hline & 45 & Broad-tailed Hummingbird & Juvenile & Male & 0 & \\
\hline & 46 & Broad-tailed Hummingbird & Juvenile & Female & 3 & \\
\hline & 47 & Broad-tailed Hummingbird & Juvenile & Female & 2 & \\
\hline & 48 & Rufous Hummingbird & Juvenile & Male & 0 & \\
\hline & 49 & Rufous Hummingbird & Juvenile & Male & 0 & \\
\hline & 50 & Rufous Hummingbird & Juvenile & Female & 0 & \\
\hline & 51 & Rufous Hummingbird & Juvenile & Female & 0 & \\
\hline
\end{tabular}


Table 2 (continued)

Mean number of grit particles per species per season is only reported for species in which we had more than one individual of the same species presenting grit in each season

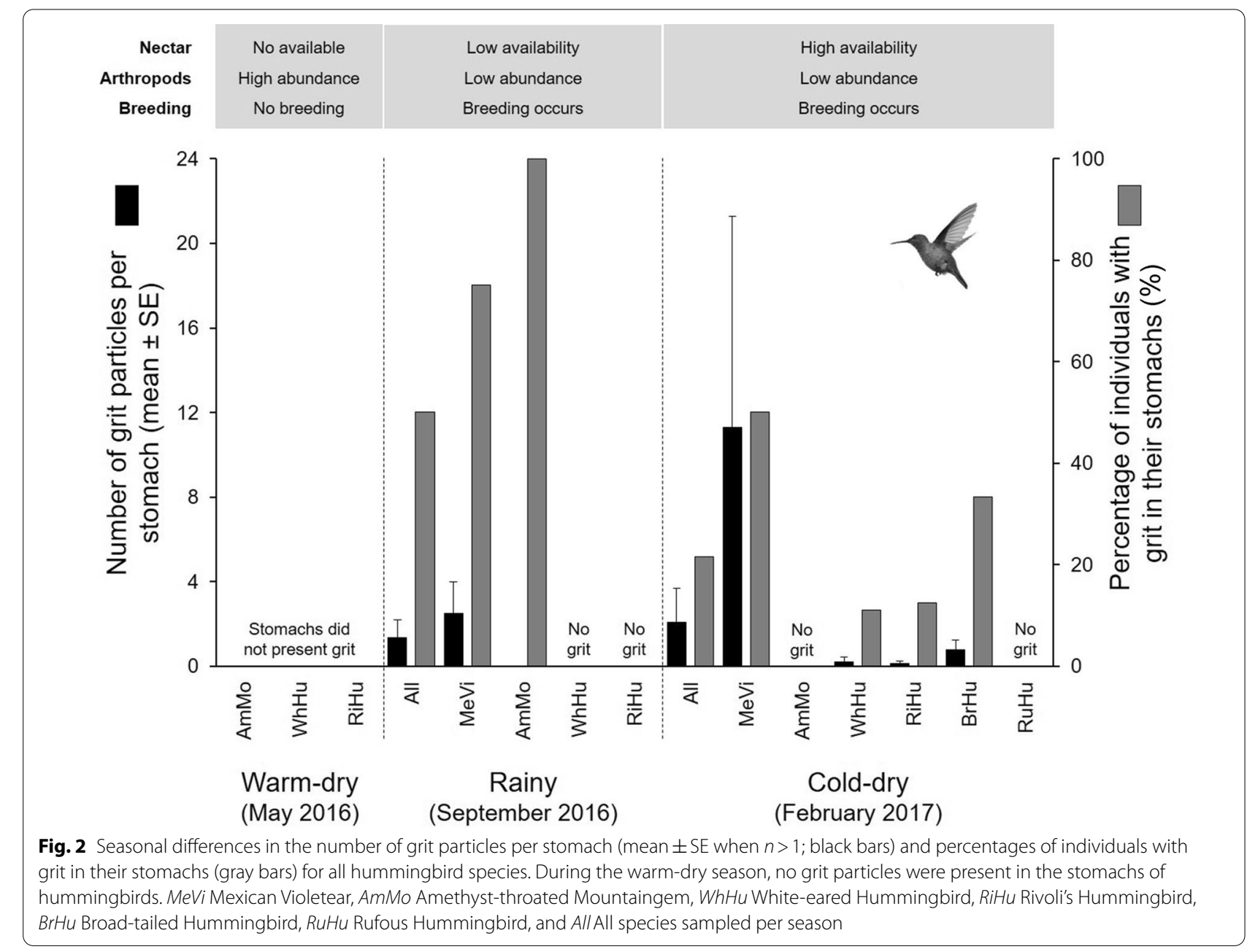

Table 3 Results of the GLM evaluating the effects of season, sex, and age on the presence of grit particles in the stomachs of hummingbirds

\begin{tabular}{lclll}
\hline Explanatory variable & Estimate & Standard error & $\chi_{1}^{\mathbf{2}}$ & $\boldsymbol{P}$-value \\
\hline Intercept & 1.85 & 0.78 & 10.39 & 0.001 \\
Rainy season & -0.68 & 0.87 & 1.10 & 0.290 \\
Warm-dry season & 1.03 & 1.19 & 1.45 & 0.220 \\
Female hummingbirds & -1.06 & 0.46 & 8.63 & 0.003 \\
Adult hummingbirds & -0.14 & 0.46 & 1.68 & 0.190 \\
\hline
\end{tabular}

the stomachs of individuals that presented grit was $2.7 \pm 2.8$ during the rainy season $(n=4 ; 2$ females, and 2 unknown sex individuals) and $9.8 \pm 20.6$ during the cold-dry season $(n=8 ; 6$ females, 1 male, and 1 unknown sex individual; see Table 2).

We found no significant differences in the average number of grit particles per stomach among hummingbird species within the cold-dry season (Kruskal-Wallis test, $\chi_{3,32}^{2}=4.9, P=0.2$; Table 2; Fig. 2). However, during this season, Mexican Violetears had the highest average number of grit particles per stomach $(11.3 \pm 24.4$, $n=6$ ), and the highest percentage of individuals with grit in their stomachs (50\%; Table 2; Fig. 2). Finally, our binomial model showed that the use of grit particles was higher in female hummingbirds when compared to males, while adult and juvenile individuals did not differ (Table 3). 


\section{Relationship between the presence of grit particles and arthropod ingestion}

The biomass of arthropods ingested by hummingbirds was not related to the number of grit particles in hummingbird stomachs (estimate $=0.00001, \mathrm{SE}=6.99$ $\left.\mathrm{e}^{-6}, \chi_{1}^{2}=3.1, P=0.07\right)$. Similarly, the chitin content of arthropods ingested by hummingbirds was not related to the number of grit particles present (estimate $=0.01$, $\left.\mathrm{SE}=0.05, \chi_{1}^{2}=0.04, P=0.8\right)$. The only male that presented grit had higher arthropod biomass in its stomach $(0.0014 \mathrm{~g}$ dry mass) than the females $(0.0006 \pm 0.0004 \mathrm{~g}$ dry mass/stomach; $\left.t_{7}=-4.56, \quad P<0.0013\right)$. Data on the arthropods ingested by hummingbirds is shown on Table 4.

\section{Discussion}

All studies that have reported ingestion of grit by hummingbirds have found that only females ingested grit (Haverschmidt 1952; Verbeek 1971; des Lauriers 1994; Adam and des Lauriers 1998; Graves 2007; Hickman et al. 2012). At our study site, we found that both female and male hummingbirds can ingest it. The use of grit particles was more frequent in females (eight of 21 sampled) than males (1 of 25 sampled). However, the only male that presented grit ingested a larger number of grit particles (61 particles) when compared to female individuals $(2.0 \pm 0.75, n=8)$. Although the percentage of hummingbirds with grit particles in their stomachs was relatively low (23.5\%, including all hummingbirds sampled), our results suggest that the use of grit by hummingbirds is more common than previously thought. However, because of our small sample size, we were unable to determine how common is the use of grit by male hummingbirds and, as a result, the differential use of grit by male and female hummingbirds requires additional study.

The use of grit by hummingbirds at our study site was seasonal, with grit in their stomachs being present only during the rainy and the cold-dry seasons. Because hummingbirds at our study site breed during both the rainy and the cold-dry seasons, these results suggest a relationship between ingestion of grit and hummingbird breeding. Others have also reported that hummingbirds only ingest grit during their breeding season (Haverschmidt 1952; Verbeek 1971; des Lauriers 1994; Adam and des Lauriers 1998; Graves 2007; Hickman et al. 2012).

Table 4 Biomass ingested and chitin content of different arthropod orders eaten by hummingbirds at our study site

\begin{tabular}{|c|c|c|c|c|}
\hline \multirow[t]{2}{*}{ Season } & \multirow[t]{2}{*}{ Species } & \multicolumn{3}{|l|}{ Ingested arthropods } \\
\hline & & Biomass (g dry mass) & Orders & $\begin{array}{l}\text { Chitin } \\
\text { content (\% } \\
\text { dry mass) }\end{array}$ \\
\hline \multirow[t]{3}{*}{ Warm-dry } & Amethyst-throated Mountaingem & 0.001 & Psocoptera & 13.3 \\
\hline & White-eared Hummingbird & $\begin{array}{l}0.0019 \pm 0.0007 \\
(n=4)\end{array}$ & Araneae, Psocoptera, Diptera & $\begin{array}{l}13.2 \pm 0.1 \\
(n=3)\end{array}$ \\
\hline & Rivoli's Hummingbird & 0.0038 & Hemiptera, Hymenoptera, Diptera & $\begin{array}{l}13.6 \pm 2.7 \\
(n=3)\end{array}$ \\
\hline \multirow[t]{4}{*}{ Rainy } & Mexican Violetear & $\begin{array}{l}0.0007 \pm 0.0005 \\
(n=4)\end{array}$ & Hemiptera, Psocoptera, Hymenoptera, Diptera & $\begin{array}{l}13.5 \pm 2.2 \\
(n=4)\end{array}$ \\
\hline & Amethyst-throated Mountaingem & 0.0006 & Hemiptera, Diptera & $\begin{array}{l}12.2 \pm 1.5 \\
(n=2)\end{array}$ \\
\hline & White-eared Hummingbird & 0.0002 & Diptera & 13.3 \\
\hline & Rivoli's Hummingbird & $\begin{array}{l}0.0001 \pm 0.00007 \\
(n=2)\end{array}$ & Unidentifiable & Unknown \\
\hline \multirow[t]{6}{*}{ Cold-dry } & Mexican Violetear & $\begin{array}{l}0.0007 \pm 0.0005 \\
(n=6)\end{array}$ & Hemiptera, Psocoptera, Hymenoptera, Diptera & $\begin{array}{l}13.5 \pm 2.2 \\
(n=4)\end{array}$ \\
\hline & Amethyst-throated Mountaingem & 0.0006 & Psocoptera & 13.3 \\
\hline & White-eared Hummingbird & $\begin{array}{l}0.0005 \pm 0.0003 \\
(n=9)\end{array}$ & Psocoptera, Hymenoptera, Diptera & $\begin{array}{l}14.4 \pm 1.8 \\
(n=3)\end{array}$ \\
\hline & Rivoli's Hummingbird & $\begin{array}{l}0.0015 \pm 0.0008 \\
(n=8)\end{array}$ & Hemiptera, Psocoptera, Hymenoptera, Diptera & $\begin{array}{l}13.5 \pm 2.2 \\
(n=4)\end{array}$ \\
\hline & Broad-tailed Hummingbird & $\begin{array}{l}0.0007 \pm 0.0004 \\
(n=9)\end{array}$ & Hemiptera, Psocoptera, Hymenoptera, Diptera & $\begin{array}{l}13.5 \pm 2.2 \\
(n=4)\end{array}$ \\
\hline & Rufous Hummingbird & $\begin{array}{l}0.0004 \pm 0.0001 \\
(n=4)\end{array}$ & Hemiptera, Psocoptera, Hymenoptera, Diptera & $\begin{array}{l}13.5 \pm 2.2 \\
(n=4)\end{array}$ \\
\hline
\end{tabular}

Mean \pm SD values of arthropod chitin content in the stomachs of hummingbirds were averaged when more than one order of arthropods was present. We were unable to identify the orders of arthropod remains ingested by Rivoli's Hummingbirds in the rainy season. In this case, the chitin content of the sample was not determined 
During the warm-dry season, no flowers were detected at our capture site (2 ha area) and two additional surrounding areas we used to sample resource abundance located 2-4 km away from it (Maya-García and Schondube, unpublished data). The hummingbirds survived in this season by ingesting more arthropods $(0.002 \pm 0.001 \mathrm{~g}$ dry mass/stomach; mean \pm SD; Maya-García and Schondube, unpublished data) than during the rainy and the cold-dry seasons $(0.0005 \pm 0.0004$ and $0.0006 \pm 0.0005 \mathrm{~g}$ dry mass/stomach, respectively) when several plant species were blooming, and nectar was abundant. This higher content of arthropods, while grit particles were absent from the hummingbird stomachs, suggests that the use of grit is not clearly linked to arthropod ingestion in the majority of the sampled species and that ingestion of grit particles could be associated with obtaining micronutrients as has been suggested previously (Verbeek 1971; des Lauriers 1994; Adam and des Lauriers 1998; Graves 2007; Estades et al. 2008; Hickman et al. 2012).

The proportion of individuals who presented grit in their stomachs was higher in juveniles $(28.5 \%$, four of 14 sampled) than in adults (21.6\%, 8 of 37 sampled), suggesting that grit ingestion could be more important for juveniles. Grit ingestion by juveniles could possibly serve two complementary roles: (1) due to their high nutritional requirements, juveniles could use grit as a source of minerals to finish their skeleton development after leaving the nest (Harper 1963; Tilgar et al. 2004; Reynolds and Perrins 2010); and (2) because arthropods are an important source of protein for tissue growth, grit particles could also be used by juveniles to facilitate the mechanical digestion of ingested prey.

The absence of significant relationships between the number of grit particles in hummingbird stomachs and the biomass of arthropods ingested by hummingbirds and ingested arthropod chitin content suggests, once again, that the primary role of grit ingestion is not related to arthropod mechanical grinding, and could be associated to obtaining minerals. However, due to the time passed between hummingbirds' capture in the nets and the moment we excised and froze their stomachs (<20 min), some of the soft-bodied arthropods could have been digested biasing our analysis. As a consequence, our results should be considered with caution. Curiously, most hard grit particles were found in the stomachs of Mexican Violetear hummingbirds, suggesting that the use of grit to obtain minerals may be limited in this species. Nonetheless, we need to consider that soft grit particles break easily and could dissolve in the acidic stomach of hummingbirds, limiting our capacity to find them and quantify their use.
Although we found no differences among hummingbird species in the number of grit particles ingested, Mexican Violetears ingested more grit particles than other species during both the rainy and the cold-dry seasons, accounting for $90.4 \%$ of all hard particles present in hummingbird stomachs. Additionally, the only male hummingbird that presented grit particles, a Mexican Violetear captured during the cold-dry season, presented a surprisingly high quantity of 61 grit particles. This individual accounted for $77.2 \%$ of all hard grit particles present in Mexican Violetear hummingbird stomachs. These two results seem to be related to the arthropod ingestion patterns of this species. Mexican Violetears ingested more adult wasps (Hymenoptera) during the rainy and the cold-dry seasons than the other hummingbird species $(19.2 \%$ and $45.5 \%$ of total arthropods present in their stomachs in both seasons, respectively; Maya-García and Schondube, unpublished data). This ingestion of hymenopterans is surprising because adult wasps have both low protein and high chitin content compared to other insect groups (Rothman et al. 2014).

\section{Conclusions}

Our results show that at the ensemble level, female hummingbirds ingested grit particles during their breeding season. This result suggests that ingested grit could have played a role as a supplement of some micronutrients, such as calcium needed for eggshell production. Although calcium content in hard grit particles was low, we were unable to analyze the elemental content of the soft grit particles and, due to the softness of these particles, we could be underestimating their ingestion. As a result, more information on ingestion, assimilation, and elemental content of soft grit particles is needed. Finally, for both male and female Mexican Violetear hummingbirds, grit particles could have the additional role of facilitating the mechanical digestion of hardbodied arthropods. Our analyses offer new insights to understand the roles played by grit in several species of hummingbirds, complementing previously published anecdotal information (Additional file 1: Table S1).

\section{Supplementary Information}

The online version contains supplementary material available at https://doi. org/10.1186/s40657-021-00298-x.

Additional file 1: Table S1. Grit ingestion by hummingbirds from the published literature. Table S2. Values used in the generalized linear models (GLM)

\section{Acknowledgements}

We thank Elisa Maya, Magdalena Valencia, Raul Valdés, Mariel Santillán,

Selene Barba, Ana Torres and Luis Maya for their crucial support in the field. We want to express our gratitude to the director of the NCNP, Biol. José Villa, 
and his team, for their generous and invaluable support to our research. We also thank Giovanni Sosa-Ceballos and Silvestre Cardona-Melchor from the Geophysics Institute of the National Autonomous University of Mexico for carrying out the grit particles analysis. Finally, we thank Carlos Lara for their insightful comments on a previous version of this manuscript. OM-G received a Consejo Nacional de Ciencia y Tecnología (CONACYT) doctoral fellowship (440805/270107). This paper is a fulfillment of the requirements to obtain the doctoral degree of the Graduate Program in Biological Sciences of the National Autonomous University of Mexico.

\section{Authors' contributions}

Conceptualization: OM-G and JES; Methodology: OM-G, JES and MO-F; Data collection: OM-G, JES and MO-F; Formal analysis and investigation: OM-G and JES; Writing - original draft preparation: OM-G and MO-F; Writing - review and editing: JES; Funding acquisition: JES; Resources: JES; Supervision: JES. All authors read and approved the final manuscript.

\section{Funding}

Research funds were Granted to JES by PAPIIT-UNAM (IN212216).

\section{Availability of data and materials}

The datasets generated and analyzed during the current study are available in the Mendeley Data repository (http://dx.doi.org/10.17632/rzhf2bjw4v.1).

\section{Declarations}

\section{Ethics approval and consent to participate}

Our methods were approved by the ethics committee of the Institute of Ecosystem Studies and Sustainability, UNAM. Permission to collect samples was provided by SEMARNAT, Mexico (SGPA/DGGFS/712/2767/14).

\section{Consent for publication}

Not applicable.

\section{Competing interests}

The authors declare that they have no competing interests.

\section{Author details}

'Posgrado en Ciencias Biológicas, Unidad de Posgrado, Coordinación del Posgrado en Ciencias Biológicas, Universidad Nacional Autónoma de México, Edificio D, 1er piso, Circuito de Posgrados, Ciudad Universitaria, Del. Coyoacán, C.P. 04510 México D.F., Mexico. ${ }^{2}$ Laboratorio de Ecología Funcional, Instituto de Investigaciones en Ecosistemas y Sustentabilidad, Universidad Nacional Autónoma de México, Antigua Carretera a Pátzcuaro No. 8701, Col. Ex Hacienda de San José de la Huerta, C.P. 58190 Morelia, Michoacán, Mexico.

Received: 25 April 2021 Accepted: 1 November 2021

Published online: 13 November 2021

\section{References}

Adam MD, des Lauriers JR. Observations of hummingbirds ingesting mineralrich compounds. J Field Ornithol. 1998; 69:257-61.

Alonso JC. Grit in the gizzard of Spanish Sparrows (Passer hispaniolensis). Vogelwarte. 1985;33:135-43.

Barrentine CD. The ingestion of grit by nestling Barn Swallows. J Field Ornithol. 1980;51:368-71.

Bird RD, Smith LB. The food habits of the Red-winged Blackbird, Agelaius phoeniceus, in Manitoba. Can Field Nat. 1964;78:179-86.

Bishton G. The diet and foraging behaviour of the Dunnock Prunella modularis in a hedgerow habitat. Ibis. 1986;128:526-39.

Brown CR. Use of gravel by Purple Martins. Auk. 1976;93:842.

Campbell RR, Leatherland JF. Changes in calcium reserves in breeding lesser snow geese (Chen caerulescens caerulescens). Acta Zool. 1983;64:9-14.

Chavez-Ramirez F, Dowd M. Arthropod feeding by two Dominican hummingbird species. Wilson Bull. 1992;104:743-7.

Comisión Nacional de Áreas Naturales Protegidas (CONANP). Plataforma de Información Climática. 2017. https://www.gob.mx/conanp/acciones-yprogramas/plataforma-de-informacion-climatica. Accessed 02 June 2019. des Lauriers JR. Hummingbirds eating. Ashes Auk. 1994;111:755-6.

Estades CF, Vukasovic MA, Tomasevic JA. Giant Hummingbirds (Patagona gigas) ingest calcium-rich minerals. Wilson J Ornithol. 2008;120:651-3.

Fair J, Paul E, Jones J. Guía para la utilización de aves silvestres en investigación. Tercera Edición. Washington, D.C.: El Consejo de Ornitología; 2010.

Firth D. Bias reduction of maximum likelihood estimates. Biometrika. 1993;80:27-38.

Gionfriddo JP, Best LB. Grit-use patterns in North American birds: the influence of diet, body size, and gender. Wilson Bull. 1996;108:685-96.

Gionfriddo JP, Best LB. Grit use by birds: a review. In: Nolan V, Ketterson ED, Thompson CF, editors. Current ornithology, vol. 15. Boston: Springer; 1999. p. 89-148.

Graves GR. Jamaican hummingbirds ingest calcareous grit. J Carib Ornithol. 2007;20:56-7.

Hainsworth FR. Foraging efficiency and parental care in Colibri coruscans. Condor. 1977;79:69-75.

Harper JA. Calcium in grit consumed by juvenile pheasants in east-central Illinois. J Wildl Manage. 1963;27:362-7.

Harper JA. Calcium in grit consumed by hen pheasants in east-central Illinois. J Wildl Manage. 1964;28:264-70.

Haverschmidt F. Notes on the life history of Amazilia fimbriata in Surinam. Wilson Bull. 1952;64:69-79.

Hickman BR, Harris JBC, Juiña ME. Apparent soil ingestion by female Esmeraldas Woodstars (Chaetocercus berlepschi) in western Ecuador. Ornitol Neotrop. 2012;23:335-40.

Howell SNG. Hummingbirds of Noth America: the photographic guide. San Diego: Academic Press Natural World; 2002.

Johnson LS, Barclay RMR. Effects of supplemental calcium on the reproductive output of a small passerine bird, the House Wren (Troglodytes aedon). Can J Zool. 1996;74:278-82.

Kopischke ED, Nelson MM. Grit availability and pheasant densities in Minnesota and South Dakota. J Wildlife Manage. 1966;30:269-75.

Korschgen LJ. Foods and nutrition of Missouri and midwestern pheasants. Trans N Am Wildl Nat Resour Conf. 1964;29:159-80.

Meinertzhagen R. Grit. Bull Br Ornithol Club. 1954;74:97-102.

Montgomerie RD, Redsell CA. A nesting hummingbird feeding solely on arthropods. Condor. 1980;82:463-4.

Mott DF, West RR, de Grazio JW, Guardino JL. Foods of the red-winged blackbird in Brown County South Dakota. J Wildlife Manage. 1972;36:983-7.

Murphy ME. Nutrition and metabolism. In: Carey C, editor. Avian energetics and nutritional ecology. Boston: Springer; 1996. p. 31-60.

Myrberget S, Norris C, Norris E. Grit in Norwegian Lagopus spp. Norweg J Zool. 1975;23:205-12.

Comisión Nacional de Áreas Naturales Protegidas (CONANP). Programa de Conservación y Manejo Parque Nacional Volcán Nevado de Colima. 2006. https://www.gob.mx/conanp/acciones-y-programas/programas-demanejo. Accessed 16 Mar 2012.

Instituto Nacional de Estadística y Geografía (INEGI). Perspectiva estadística: Jalisco. México: INEGl; 2011.

Remsen JV, Stiles G, Scott PE. Frequency of arthropods in stomachs of tropical hummingbirds. Auk. 1986;103:436-41.

Reynolds SJ. Uptake of ingested calcium during egg production in the Zebra Finch (Taeniopygia guttata). Auk. 1997;114:562-9.

Reynolds SJ, Perrins CM. Dietary calcium availability and reproduction in birds. In: Thompson CF, editor. Current ornithology, vol. 17. New York: Springer; 2010. p. 31-74.

Rico-Guevara A. Morphology and arthropod foraging by high Andean hummingbirds. Ornitol Colomb. 2008;7:43-58.

Rico-Guevara A, Rubega MA, Hurme KJ, Dudley R. Shifting paradigms in the mechanics of nectar extraction and hummingbird bill morphology. Integr Org Biol. 2019;1:oby006.

Rothman MJ, Raubenheimer D, Bryer AH, Takahashi M, Gilbert CC. Supplementary Online Table: Nutritional compositions of insects from the published literature. 2014. https://doi.org/10.1016/j.jhevol.2014.02.016. Accessed 02 Oct 2018.

Russell SM, Russell RO, Pollock J, Hill A. The North American banders' manual for banding hummingbirds. USA: The North American Banding Council; 2019.

Sadler KC. Grit selectivity by the female pheasant during egg production. J Wildlife Manage. 1961;25:339-41. 
Schondube JE. Differences in nectar use potential in a guild of birds: a gut's view. Ornitol Neotrop. 2012;23:97-113.

Sokal RR, Rohlf FJ. Biometry. New York: WH Freeman; 1995.

Stiles FG. Behavioral, ecological and morphological correlates of foraging for arthropods by the hummingbirds of a tropical wet forest. Condor. 1995;97:853-78.

Taylor TG. The provision of calcium and carbonate for laying hens. In: Swan $H$, Lewis D, eds. Proceedings of the fourth nutrition conference for feed manufacturers. London: J and A Churchill Publisher; 1970. p. 108-28.

Tilgar V, Mänd R, Ots I, Mägi M, Kilgas P, Reynolds SJ. Calcium availability affects bone growth in nestlings of free-living great tits (Parus major), as detected by plasma alkaline phosphatase. J Zool. 2004;263:269-74.
Triplehorn AC, Johnson FN. Borror and delong's introduction to the study of insects. 7th ed. USA: Thomson Brooks/Cole; 2005.

Verbeek NAM. Hummingbirds feeding on sand. Condor. 1971;73:112-3.

Williamson SL. A field guide to hummingbirds of North America (Peterson Field Guide). New York: Houghton Mifflin; 2001.

Zar JH. Biostatistical analysis. 4th ed. New Jersey: Prentice-Hall; 1999.

Ziswiler V, Farner DS. Digestion and the digestive system. In: Farner DS, King JR, Parkes KC, editors. Avian biology, vol. 2. New York: Academic Press; 1972. p. 343-430.
Ready to submit your research? Choose BMC and benefit from:

- fast, convenient online submission

- thorough peer review by experienced researchers in your field

- rapid publication on acceptance

- support for research data, including large and complex data types

- gold Open Access which fosters wider collaboration and increased citations

- maximum visibility for your research: over $100 \mathrm{M}$ website views per year

At BMC, research is always in progress.

Learn more biomedcentral.com/submissions 